удк 349.2

DOI https://doi.org/10.32837/pyuv.v1i4(29).401

\author{
О.Г.Реуцьков \\ orcid.org/0000-0001-8612-233X \\ здобувач кафедри правознавства \\ Східноукраїнського національного університету ілені Володимира Даля
}

\title{
ПОЗИТИВНИЙ ДОСВІД ГРУЗІЇ ЩОДО ПРАВОВОГО РЕГУ ЛЮВАННЯ АТЕСТАЦІЇ ПРАЦІВНИКІВ ПОЛІЦІї: НАПРЯМИ ЗАПОЗИЧЕННЯ В НАЦІОНАЛЬНЕ ТРУДОВЕ ЗАКОНОДАВСТВО
}

Актуальність теми. Питання транссормаційних процесів у правоохоронній сфері ще з моменту проголошення Україною незалежності перманентно перебували в сфері інтересів вітчизняних науковців. Проголошений курс до євроінтеграції потребував приведення у відповідність до європейських стандартів усіх сфер суспільного життя. Правоохоронна сфера довгий час вважалась в Україні однією iз найбільш проблемних, і в результаті суспільна довіра до органів внутрішніх справ взагалі зникла під час подій Революції Гідності. Стало очевидним, що органи міліції потребують кардинальних як структурних, так і кадрових змін. Актуальність цього курсу посилилась утвердженням євроінтеграційних цілей нашої держави та визначенням новосформованим урядом держави першочергових реформ, метою яких було викорінення корупції та беззаконня з судової та правоохоронної систем. Серед запланованих реформ було і переформатування органів внутрішніх справ, одним із важливих етапів якого стало прийняття Закону України «Про Національну поліцію» від 02.07.2015 № 580-VIII [1]. Деякий час, до вступу в дію цього нормативно-правового акту, поліція працювала відповідно до Закону України «Про міліцію» від 20.12.1990 № 565-XII [2], і як продемонстрував подальший досвід функціонування цього органу, до сьогоднішнього дня мають місце складнощі у зміні принципів його діяльності.

Під час реформування органів Національної поліції України за основу був взятий досвід зарубіжних держав, які раніше успішно здійснили такі перетворення. Однією із держав, досвід якої було взято за основу, була Грузія. Для цього до роботи над реформою в Україну були запрошені грузинські фахівці, перед якими стояла задача у найкоротші строки створити в Україні дієвий та ефективний правоохоронний орган, який служить суспільству шляхом забезпечення охорони прав і свобод людини, протидії злочинності, підтримання публічної безпеки і порядку. 17 листопада 2015 року було представлено концепцію «100 днів якості Національної поліції України» [3], яка являла собою документ, що містив низку революційних за змістом завдань реформування органів внутрішніх справ нашої держави, запланованих для реалізації упродовж 100 днів. Його авторами була грузинська команда реформаторів у складі заступника міністра Еки Згуладзе та новопризначеного керівника Національної поліції Хатії Деканоїдзе, які успішно провели аналогічну реформу в Грузії. Основними заходами реформи органів внутрішніх справ України декларувалась переатестація працівників поліції, звільнення від колишніх корумпованих кадрів, а також залучення до служби у новій Національній поліції великої кількості нових, мотивованих, кваліфікованих кадрів. Окрім цього, було заплановано запровадження нової оцінки діяльності поліції, відхід від традиційних числових показників, оцінка рівня корупції у підрозділах поліції, а також ряд інших нових процедур у діяльності Національної поліції, які в теорії мали наблизити цей орган до кращих європейських та світових стандартів функціонування правоохоронних органів. Було заплановано повну зміну підходів до перевірки й оцінювання професійної кваліфікації працівників поліції на предмет їх відповідності займаній посаді або здійснюваній роботі. Проте, як засвідчує досвід функціонування цього органу, побудувати Національну поліцію як правоохоронний орган європейського рівня в Україні так і не вдалось. Система правоохоронних органів, яка б цілком відповідала міжнародним стандартам, в Україні так і не сформована до сьогодні. Критиці у суспільстві традиційно піддаються невисока ефективність професійної діяльності поліції, корумпованість працівників, слабко налагоджена взаємодія із громадянами, невиконання завдань забезпечення охорони прав і свобод людини, протидії злочинності, підтримання публічної безпеки і порядку. Це варто пов'язати і з проблематикою прийнятого законодавства, яка була нами проаналізована в попередній статті, і з відсутністю політичної волі на запровадження принципово нових стандартів діяльності цього правоохоронного органу. Проте однією із основних причин невдачі реформи Національної поліції став провал процедури переатестації, внаслідок якої кадровий склад новоутвореного органу фактично не змінився. Відповідно, у самих «переатестованих» правоохоронців воля навчитись працювати в нових умовах також була відсутня, і всі попередні проблеми так і залишились актуальними. 
Стан дослідження. Серед дослідників зарубіжного досвіду реформування органів поліції відзначимо внесок таких авторів, як В.А. Багрій, I.В. Балабан, В.М. Бесчастний, В.М. Білик, C.I. Братков, О.М. Брисковська, В.Д. Гвоздецький, В.О. Заросило, В.О. Ільницький, М.І. Іншин, М.Ф. Криштанович, I.М. Охріменко, О.С. Проневич, В.О. Січкар, О.Ю. Татаров, І.В. Фільштейн, О.П. Цуркан, Д.В. Швець, О.Н. Ярмиш. Разом із тим провал процедури атестації та недоліки у правовому регулюванні цієї процедури свідчить про те, що в сучасних умовах залишається актуальним для дослідження питання пошуку шляхів удосконалення зазначеного інституту на основі позитивного зарубіжного досвіду правового регулювання атестації працівників поліції, адже у багатьох зарубіжних державах ці процеси пройшли більш ефективно.

Виклад основного матеріалу. Так, серед країн, досвід яких варто дослідити першочергово, варто виділити Грузію, адже саме реформа цієї держави стала основою для проведення української реформи поліції, а грузинські фахівці були активними учасниками української реформаторської діяльності в правоохоронній сфері. Нова сучасна правоохоронна система Грузії побудована на міжнародному досвіді, передусім Сполучених Штатів Америки та провідних країн Європи. Цей досвід був адаптований до національних особливостей Грузії, а Україна своєю чергою здійснила спробу адаптувати грузинський досвід до своїх реалій та умов. Грузинський досвід реформування поліції отримав позитивну оцінку західних та українських спеціалістів й експертів як найуспішніший на території колишнього Радянського Союзу та постійно досліджується науковцями різних держав.

Як відзначає I.В. Фільштейн, одним із позитивних результатів реформи стала зміна відношення громадян до правоохоронних органів, а також поява поваги населення до поліції. Професія поліцейського означає повагу, громадяни вже не бачать в працівникові поліції злочинця в погонах, а тільки їх захисника та захисника справедливості [4, с. 91]. Втім, якщо звернутись до статистичних даних, то можна відзначити, що за останні роки рівень довіри суттєво знизився. Так, в 2009 році рівень довіри громадян до поліції в Грузії становив $82 \%$, що є дуже серйозним показником навіть на світовому рівні [5]. Проте у 2019 році цей показник вже становить 48\% [6]. Це значно більше, ніж в України, проте не можна не відзначити негативну тенденцію суттєвого падіння довіри за останнє десятиліття. Але водночас відсутні підстави заперечувати успішність реформи поліції в Грузії, адже ряд позитивних елементів грузинської реформи були використані під час реформування правоохоронної системи України, а також низку елементів було б доречно використати у сучасних умовах.

Насамперед варто звернути увагу на те, що під час формування нової поліції реформатори виходили з першочергової необхідності ліквідації підрозділів, які повністю були паралізовані корупцією. Найбільш проблемним для населення був підрозділ дорожньої поліції, тому було прийнято рішення про його ліквідацію. Було звільнено 14 тисяч iї співробітників, а замість цього підрозділу, керуючись досвідом США, було створено єдину патрульну службу, яка, крім забезпечення правопорядку та безпеки на дорогах, стежила за порядком на вулицях, сприяла у вирішенні побутових проблем [7, с. 7]. Логіка реформаторів виходила з того, що дорожня поліція фактично перетворилася на цілковите злочинне угрупування, де в орбіту корупції, хабарництва втягувалися навіть особи, які бажали працювати чесно та 3 дотриманням закону. В результаті ліквідація дорожньої поліції не призвела до жодних серйозних наслідків у сфері забезпечення безпеки дорожнього руху, оскільки особовий склад дорожньої поліції практично не займався своїми професійними обов'язками. Окрім дорожньої поліції, були ліквідовані підрозділи, які не впливали на криміногенну обстановку, були зайвими в системі охорони громадського порядку та безпеки, протидії правопорушенням [4, с. 91]. При цьому варто звернути увагу на те, що в Україні було прийнято спеціальне законодавство, яке врегулювало процедуру переатестації працівників міліції, а в Грузії таке спеціальне законодавство не було прийнято. Як нами відзначалось раніше, недосконалість положень Закону України «Про Національну поліцію» від 02.07.2015 № 580-VIII [1] та Інструкції про порядок проведення атестування поліцейських [8] стала однією із передумов, чому переатестація працівників міліції не призвела до очікуваних результатів. Для порівняння, Закон Грузії «Про поліцію» було прийнято лише у 2013 році [9], тобто фактично через 10 років після проведеної реформи поліції. Це означає, що «переатестація» працівників міліції здійснювалась згідно із законодавством про поліцію 1993 року, яке, очевидно, не визначало жодних норм, які урегульовували цю процедуру. Те ж саме стосується і новоприйнятого Закону Грузії «Про поліцію» від 04.10.2013 року №1444-Ic [9]. Аналіз його норм дозволяє зробити висновок про те, що зміст цього нормативно-правового не містить жодних норм, подібних до статті 57 Закону України «Про Національну поліцію» від 02.07.2015 № 580-VIII [1]. Також у правовій системі Грузії відсутні нормативно-правові акти, близькі за змістом до Інструкції про порядок проведення атестування поліцейських [8].

Серед норм законодавства про поліцію, які безпосередньо стосуються питань, пов'язаних із 
атестацією, відзначимо, що згідно зі статтею 37 Закону Грузії «Про поліцію» від 04.10.2013 року №1444-Iс [9] критеріями для прийому особи на службу в органи поліції є вік, володіння державною мовою Грузії, особисті і ділові якості, рівень освіти, фізична підготовка і стан здоров'я. Кадровий підрозділ Міністерства і спеціальна комісія відбирають кандидатів для прийняття на службу в поліцію, перевіряють їх стан здоров’я, фізичну підготовку, освіту і ділові якості. У разі прийняття на спеціальні посади кандидати проходять в Академії Міністерства відповідну освітню програму чи курс спеціальної підготовки до або після прийняття на службу. Серед підстав для звільнення, передбачених статтею 41 цього нормативно-правового акту, відзначимо такі підстави, як скорочення штатів або реорганізацію, яка потягнула за собою скорочення штатів, що у майбутньому значно полегшує процедуру звільнення працівників поліції під час наступних реформ та реорганізацій поліції Грузії. Ще однією підставою для звільнення є ліквідація структурного підрозділу. Тобто у таких випадках, як ті, що мали місце у 2004 році, коли була ліквідована дорожня поліція та звільнено 14 тисяч її співробітників, такі звільнення відбуватимуться строго на підставі пункту «в» частини 1 статті 41 Закону Грузії «Про поліцію» від 04.10.2013 року № 1444-Iс [9]. Для порівняння, частина 1 статті 77 Закону України «Про Національну поліцію» від 02.07.2015№ 580-VIII[1] також встановлює подібне положення - підпункт 4 частини 1 передбачає можливість звільнення працівника поліції у зв'язку із скороченням штатів або проведенням організаційних заходів. Відповідно, реформування органів Національної поліції можна класифікувати, як «проведення організаційного заходу». Загалом, аналізуючи перелік підстав для звільнення працівника поліції, зробимо припущення, що зміст цієї норми формулювався із урахуванням грузинського законодавства, адже відповідні положення є, по суті, ідентичними. Звернемо увагу на те, що Закон Грузії «Про поліцію» від 04.10.2013 року № 1444-Iс [9] взагалі не передбачає норм, пов'язаних із професійним навчанням поліцейських у процесі проходження служби. Закон України «Про Національну поліцію» від 02.07.2015 № 580-VIII [1] такі норми встановлює, й окрім цього, питання підвищення працівниками поліції ділових, професійних, особистих якостей, їх освітнього та кваліфікаційного рівня, врегульовується на підзаконному рівні [10].

Отже, здійснивши порівняння законодавства, яке урегульовує атестацію працівників поліції в Україні та Грузії, варто зробити висновок, що у цьому аспекті законодавство нашої держави є досконалішим. У Законі України «Про Національну поліцію» від 02.07.2015 № 580-VIII [1] прямо передбачено норми, присвячені регламентації цієї процедури, прийнято спеціальне законодавство. По суті, законодавство Грузії не передбачає процедури атестації працівників поліції у тому вигляді, у якому вона функціонує в українському законодавстві. Досвід цієї держави є корисним насамперед у практичній реалізації тих процесів, в реалізації яких Україна не досягла успіхів.

У Грузії протягом лише одного дня було звільнено 16 тисяч співробітників поліції, а всього протягом двох перших років реформування з 90 тисяч співробітників поліції було звільнено 75 тисяч [7, с. 7]. В Україні ж під час реформи поліції за результатами атестації було звільнено 5436 осіб із 86219 , із яких 2,1 тисяча осіб в результаті все одно поновились на посадах шляхом звернення до суду [11]. Організація та нормативно-правове регулювання звільнення неатестованих службовців були забезпечені таким чином, що у звільнених працівників поліції залишились можливості оскаржувати такі рішення, зокрема у зв'язку із безпідставністю звільнення. Тобто результати переатестації в обох державах не є співмірними, і тому, як наслідок, реформа поліції в Україні зазнала поразки, адже побудова нового органу із старими кадрами об'єктивно неможлива. Багато хто в Грузії непокоївся про реакцію поліцейських та суспільства на масове звільнення. Зрештою були прийняті рішення на кшталт звільнення усього складу дорожньої поліції, і вони були сприйняті як єдиний шлях до створення надійної та компетентної поліції. Аби пом'якшити удар, Уряд виплатив їм заробітну плату за 2 місяці та застосував амністію щодо вже скоєних злочинів. Деякі офіцери залишили свої посади без суперечок, інші приєдналися до опозиції. Очікуваний хаос не настав - багато очевидців тих подій вважають, що без дорожньої поліції дороги стали навіть безпечнішими, оскільки ніхто вже постійно не зупиняв автомобілістів. Згодом було створено нову службу патрульної поліції [12, с. 16]. В Грузії було створено такі умови, за яких неатестовані працівники поліції не поновлювались на посаді у судовому порядку. І при цьому всьому досвід Грузії продемонстрував, що одночасне звільнення великої кількості правоохоронців не стає катастрофою для держави, яка поступово заповнювала вакантні посади новими працівниками.

Висновки. Отже, дослідження позитивного зарубіжного досвіду правового регулювання атестації працівників поліції засвідчило, що для України найбільш доцільно продовжити реформу національної поліції на основі досвіду тих держав, на які і раніше опирався вітчизняний законодавець. Досвід Грузії є взірцем того, як ефективно провести реформу поліції в умовах, близьких до українських. Для цього передусім важливо нарешті оновити та оптимізувати кадровий склад Національної поліції. 


\section{Jimepamypa}

1. Про Національну поліцію: Закон України від 02.07.2015 № 580-VIII. Відомості Верховної Ради. 2015. № 40-41. ст.379

2. Про міліцію: Закон України від 20.12.1990 № 565-XII. Відомості Верховної Ради УРСР. 1991 р. № 4 . стор. 95 . стаття 20

3. Концепція «100 днів якості Національної поліції України»: офіційний веб-ресурс Національної поліції України. URL: https: npu.gov.ua/uk/publish/ article/1714126 (дата звернення 21.07.2019 року).

4. Фільштейн І.В. Правова регламентація та організаційні засади створення та діяльності поліції Грузії: узагальнення досвіду [Текст] : дис. ... канд. юрид. наук : 12.00.07; Відкрит. міжнар. ун-т розвитку людини «Україна». Київ, 2016. 220 с.

5. Бюро полицейских услуг»: как проходила реформа грузинской полиции : веб-ресурс «Открытый университет». URL: https: openuni.io/about/ (дата звернення 21.07.2019 року)

6. Результаты исследования: Доверие к институтам в Грузии низкое : веб-ресурс «Civil.ge». URL: https: civil.ge/ru/archives/301253 (дата звернення 21.07.2019 року)

7. Реформування поліції: міжнародний досвід. Інформаційна довідка, підготовлена Європейським інформаційно-дослідницьким центром на запит народного депутата України. URL: http: euinfocenter.rada. gov.ua/uploads/documents/29325.pdf (дата звернення 21.07.2019 року)

8. Про затвердження Інструкції про порядок проведення атестування поліцейських: Наказ МВС України від 17.11.2015 № 1465. Офіиійний вісник України. 2015 р. № 90. стор. 234. стаття 3073. код акта $79475 / 2015$

9. О полиции: Закон Грузии от 04.10.2013 года №1444-Ic. URL: https: matsne.gov.ge/ru/document/ view $/ 2047533$ ? publication $=23 \quad$ (дата звернення 21.07.2019 року).

10. Про затвердження Положення про організацію післядипломної освіти працівників Національноі поліції: Наказ МВС України від 24.12.2015 № 1625. Офіиійний вісник України. 2016 р. № 11. стор. 173. стаття 485. код акта 80657/2016

11. Звіт 3 виконання Національною поліцією України упродовж 2017 року Державної програми щодо реалізації засад державної антикорупційної політики в Україні (Антикорупційної стратегіi) на 2015-2017 роки та Антикорупційної програми НПУ на 2017 рік. URL: https: google.com.ua/url?sa=t\&rc $\mathrm{t}=\mathrm{j} \& \mathrm{q}=\& \operatorname{esr} \mathrm{c}=\mathrm{s} \&$ source $=$ web\& $\mathrm{cd}=2 \& \mathrm{ved}=2 \mathrm{ahUKEwj}$ ov_Lg 4 eTnAhXQ_CoKHay1AIMQFjABegQIBRAB\&u $\mathrm{rl}=\mathrm{http} \% 3 \mathrm{~A} \% 2 \mathrm{~F} \% 2 \mathrm{Fpatrol}$.police.gov.ua $\% 2 \mathrm{Fwp}-\mathrm{co}$ ntent $\% 2$ Fuploads $\% 2$ F $2018 \% 2$ F09\%2FZvit_2017-1. doc\&usg=AOvVaw0WU5y9nFPwEGBKDEj-J8cC (дата звернення 21.07.2019 року).

12. Боротьба з корупцією у сфері державних послуг: Хроніка реформ у Грузії. Міжнародний банк реконструкції та розвитку Міжнародна асоціація розвитку Світовий банк. Вашингтон. 2012. 132 с.

\section{Анотація}

Реуцьков О. Г. Позитивний досвід Грузії щодо правового регулювання атестації працівників поліції: напрями запозичення в національне трудове законодавство. - Стаття.

У статті проаналізовано специфіку правового регулювання атестації працівників поліції у Грузії. Визначено позитивні та негативні аспекти правового регулювання атестації працівників поліції в цій країні. Сформульовано напрями запозичення у національне трудове законодавство позитивного досвіду Грузії щодо правового регулювання атестації працівників поліції. 3'ясовано, що в Україні число звільнених працівників було, порівняно із грузинським досвідом, незначним, і при цьому більшість із звільнених в результаті поновились на посадах. Організація та нормативно-правове регулювання звільнення неатестованих службовців були забезпечені таким чином, що у звільнених працівників поліції залишились можливості оскаржувати такі рішення, зокрема у зв'язку із безпідставністю звільнення. В Грузії було створено такі умови, за яких неатестовані працівники поліції не поновлювались на посаді у судовому порядку. I при цьому всьому досвід Грузії продемонстрував, що одночасне звільнення великої кількості правоохоронців не стає катастрофою для держави, яка поступово заповнювала вакантні посади новими працівниками. Звернуто увагу на те, що під час формування нової поліції реформатори виходили з першочергової необхідності ліквідації підрозділів, які повністю були паралізовані корупцією. Найбільш проблемним для населення був підрозділ дорожньої поліції, тому було прийнято рішення про його ліквідацію. Зроблено висновок, що в Законі України «Про Національну поліцію» прямо передбачено норми, присвячені регламентації процедури атестації працівників поліції, прийнято спеціальне законодавство. По суті, законодавство Грузії не передбачає процедури атестації працівників поліції у тому вигляді, у якому вона функціонує в українському законодавстві. Для України найбільш доцільно продовжити реформу національної поліції на основі досвіду тих держав, на які і раніше опирався вітчизняний законодавець. Досвід Грузії є взірцем того, як ефективно провести реформу поліції в умовах, близьких до українських. Для цього насамперед важливо нарешті оновити та оптимізувати кадровий склад Національної поліції.

Ключові слова: правове регулювання, атестація працівників, працівники поліції, національна поліція, праця.

\section{Summary}

Reutskov O.H. A positive experience of Georgia in the legal regulation of police officers appraisal: directions of borrowing in the national labour legislation. - Article.

In the article the specifics of the legal regulation of the certification of police officers in Georgia are analyzed. Positive and negative aspects of the legal regulation of police officers' appraisal in this country have been identified. The directions of borrowing into the national labor legislation of the positive experience of Georgia regarding the legal regulation of police officers' attestation are formulated. It was found that in Ukraine the number of dismissed workers was insignificant in comparison with the Georgian experience, and most of the dismissed were resumed as a result. The organization and regulation of the dismissal of non-certified employees were ensured in such a way that the dismissed police officers had the opportunity to appeal against such decisions, in particular because of the groundless dismissal. Georgia has created conditions under which unqualified police officers have not been reinstated. And yet, Georgia's experience has shown that the simultaneous dismissal of a large number of law enforcement officers does not become a disaster for a state that is gradually filling vacant positions with new employees. It should be noted that in the formation of the new police reformers proceeded from the overriding need to eliminate units 
that were completely paralyzed by corruption. The police department was the most problematic for the population, so it was decided to eliminate it. It is concluded that the Law of Ukraine "On the National Police" explicitly stipulates the rules on the regulation of the procedure of certification of police officers, adopted special legislation. As a matter of fact, Georgian law does not provide for the procedure of certification of police officers in the form in which it functions in Ukrainian law. For Ukraine, it is most advisable to continue reforming the national police, based on the experience of those countries that have been backed by the domestic legislator. Georgia's experience is a model of how to effectively reform police in a situation close to the Ukrainian one. First of all, it is important to finally update and optimize the staffing of the National Police.

Key words: legal regulation, employee certification, police officers, national police, labor. 